\title{
RADIO FREQUENCY IDENTIFICATION (RFID) AND EASE OF LIFE
}

\author{
Prof. (Dr.) Vishwajeet V. Jituri ${ }^{* 1} 凹$ \\ ${ }^{* 1}$ Dean- Academics in Lingaya's Vidyapeeth (Formerly known as Lingaya's University), Haryana, \\ India
}

DOI: https://doi.org/10.29121/granthaalayah.v8.i8.2020.811

Article Type: Research Article

Article Citation: Prof. (Dr.)

Vishwajeet V. Jituri. (2020). RADIO

FREQUENCY IDENTIFICATION

(RFID) AND EASE OF LIFE.

International Journal of Research -

GRANTHAALAYAH, 8(8), 49-55.

https://doi.org/10.29121/granthaa

layah.v8.i8.2020.811

Received Date: 19 July 2020

Accepted Date: 19 August 2020

Keywords:

RFID

Tag

Reader

Barcode

Toll

Transportation

Agriculture

Shopping

Retail

Library

\section{ABSTRACT}

The usage of RFID technology is rapidly increasing. The RFID system provides distinct advantages over the traditional barcode system. The RFID technology is being used in many areas like toll collection, shopping and retail, agriculture, transportation, industries, academics etc. There are some limitations also with the RFID technology including the privacy issues. This paper describes some of the RFID uses which result in ease of life.

\section{INTRODUCTION}

Radio Frequency Identification (RFID) is a generic term for technologies that use radio waves to automatically identify people or objects from a short distance of several inches to hundreds of feet. RFID is a technology by way of which an object can be identified automatically. This is similar to the other identification techniques like barcode, magnetic strip, integrated circuit (IC) smart card, optic character recognition (OCR), voice recognition, fingerprint and optical strip etc. RFID is in use since 1970s and therefore not a new technology. However, in recent times, the RFID technology is growing rapidly in many applications. (Parkash, Kundu, \& Kaur, 2012)

In a RFID system, the combination of tag and reader is used for the identification purpose. A code is stored in the RFID tag and this tag is attached to a physical object. With this tag in place, the object becomes uniquely identifiable. The RFID tag transmits the code, which is captured by the reader, thereby getting information about the object. (Parkash, Kundu, \& Kaur, 2012)

(C) 2020 The Author(s). This is an open access article distributed under the terms of the Creative Commons Attribution License, which permits unrestricted use, distribution, and reproduction in any medium, provided the original author and source are credited. 
A typical RFID system consists of the following components as shown in Figure 1.

- RFID tag (electronic label)

- Antenna (medium for tag reading)

- Reader/ module (reads tag information)

- Communication infrastructure (enable reader/ RFID to work through IT infrastructure)

- Server and application software (user database/ application/ interface)

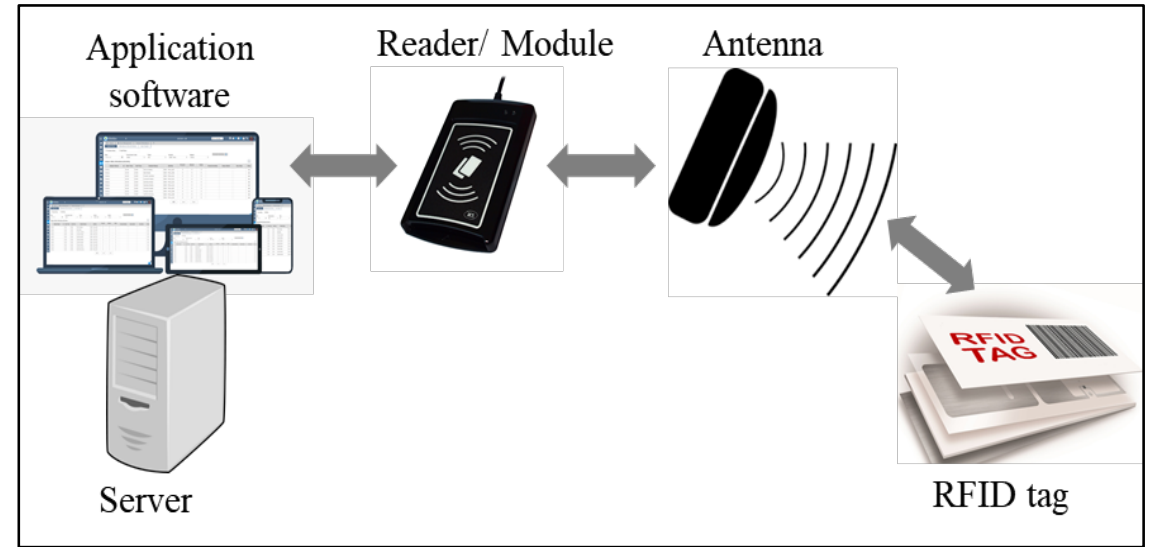

Figure 1

Source of images: (Biometric Rf - Rfid Software, n.d.), (NFC Reader Writer UID uitlezen, n.d.), (RFID reader clip art, n.d.), (The different uses of RFID readers in India, n.d.)

RFID offers much advantage over traditional identification device like barcode. To read the barcode, the barcode scanner needs to be in line of sight with the label. It means that the manual movement of the objects or scanner is necessary. RFID, on the other hand can read data from tag without line of sight. Also, no alignment is necessary in RFID technology. (Parkash, Kundu, \& Kaur, 2012)

RFID and barcode technologies are similar that both help to automate the process, improve operations management, reduce labour, eliminate human errors and fetch the data. RFID is dissimilar in the ways that tag can be embedded and hidden, no line-of-sight required, can be reprogrammed on-the-fly, can be read through variety of material like wood, plastic, cardboard etc. except metals, and can work in harsh environment like outdoors, around chemicals, moisture and high temperatures. (Kaur, Sandhu, Mohan, \& Sandhu, 2011)

There are some varieties in RFID systems depending upon the technology. (Cui, Zhang, Gao, Meng, \& Li, 2019)

- Passive RFID tag (without battery)

- Active RFID tag (with battery)

- Chip (more data storage) and chip-less (less data storage) RFID tag

- Near-field system (sensing range is very less) and far-field system (sensing range is more)

The RFID technology has the advantages of high reading speed, working even in presence of a barrier, longer read range, fast scanning, multiple data carrying capability, and flexibility etc. Due to these benefits, the RFID system is gaining attention in many areas like transportation, agriculture, manufacturing industries, shopping, academics etc. Some of the applications of RFID technology resulting in ease of life are described below.

\section{TOLL COLLECTION}

Traditionally, the toll collection of vehicles has been a manual system as per the following procedure given in Figure 2.

- Vehicle stops at a toll counter

- Toll payment is given by cash, credit card, online method or through smart card

- Payment receipt is generated by the toll person and the toll gate is opened

- Vehicle passes through the toll gate and the next vehicle in queue comes to the toll counter 

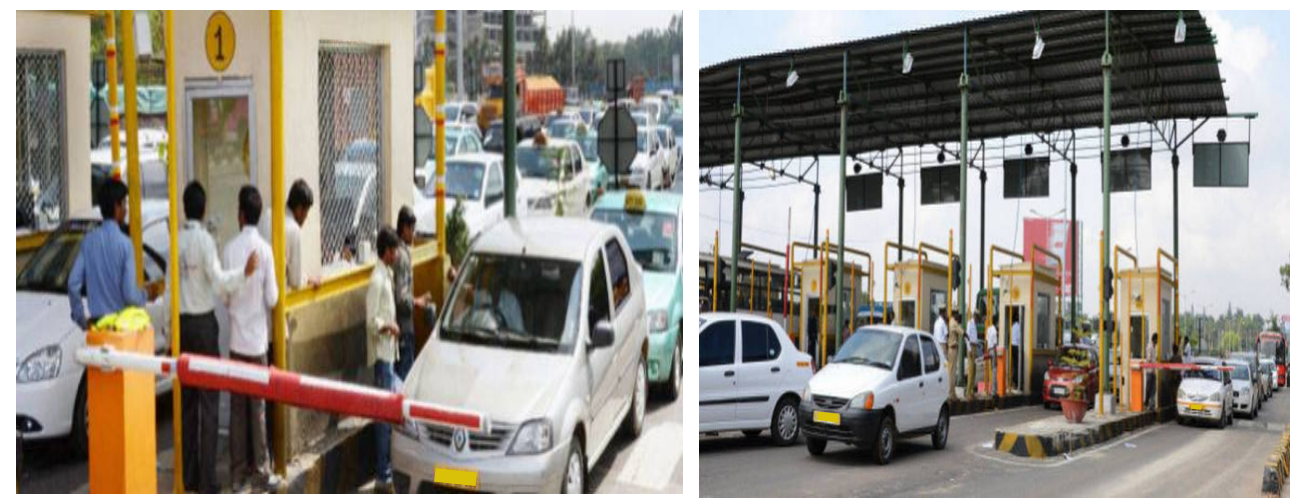

[Source: (Nair, 2011)]

Figure 2

The above procedure even when efficient, allows around 60 to 100 vehicles to pass in one hour. So, if the traffic is heavy, more toll counters need to be opened, otherwise the wait time increases causing frustration to the customers and unnecessary fuel consumption and pollution.

The automatic toll collection uses RFID technology to allow the collection of toll charges by automated process. The RFID reader mounted at toll booth reads the prepaid RFID tag fixed on vehicle's windshield, the toll amount is deducted, and the gate is opened automatically.

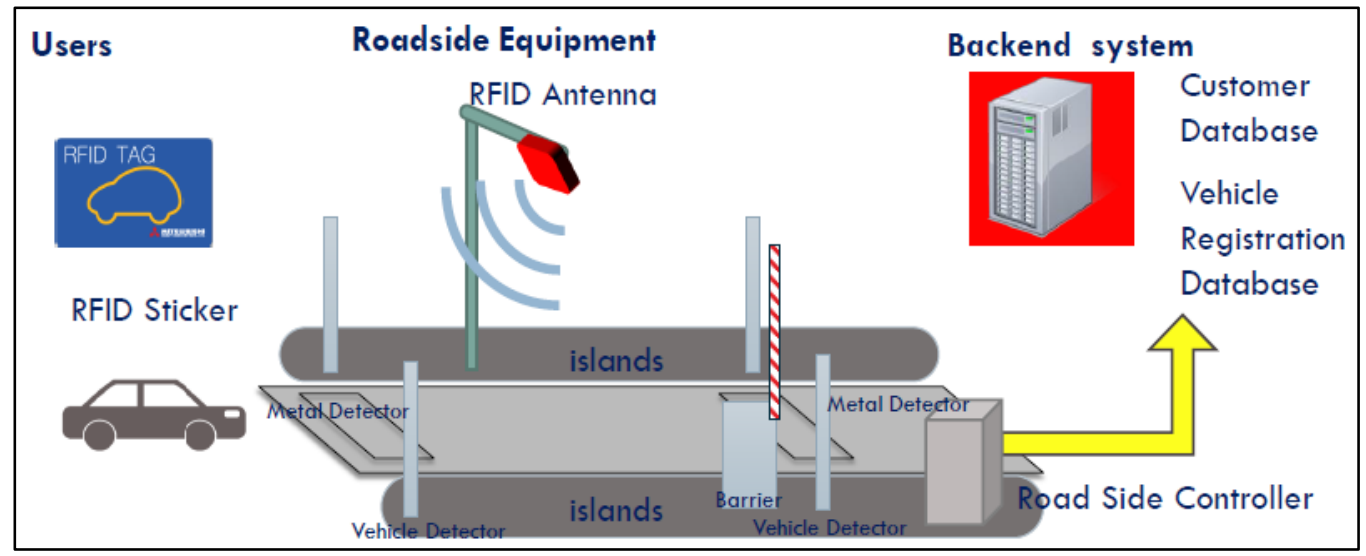

Figure 3

[Source: (Mitsubishi Heavy Industries Machinery Systems, 2018)]

The benefits of RFID based automated toll collection system are:

- Faster and efficient service with shorter queues at toll plazas due to passage of 300 to 400 vehicles per hour. Moreover, a fast RFID system can allow passage of 1500 vehicles per hour with barrier and 2500 vehicles per hour without barrier (Mitsubishi Heavy Industries Machinery Systems, 2018).

- Very less manual intervention

- Ability to make payments by keeping a balance on the card itself

- Minimization of fuel wastage and reduced emissions by reducing waiting time of vehicles in queue

- Lowered toll collection costs for toll operator

- Expanded capacity without building more infrastructures

- Satisfaction of the customers

- (Singh, Saha, Karmakar, \& Dutta, 2018)

\section{RAILWAYS}

The first regular use of RFID in U.S railways was done in 1985 on a unit train carrying coal from the Kerr McGee coal mine in southern Illinois to a power plant in St Louis. The RFID system design requirements included 
ruggedness, accuracy, reliability, economy and electronic as well as mechanical designs. The benefits to the railway operator were improved customer service, by knowing where the equipment was and providing tailored service, reduced operating costs obtained through better utilisation of equipment, and reduction of mistakes and automation. (French, 2008)

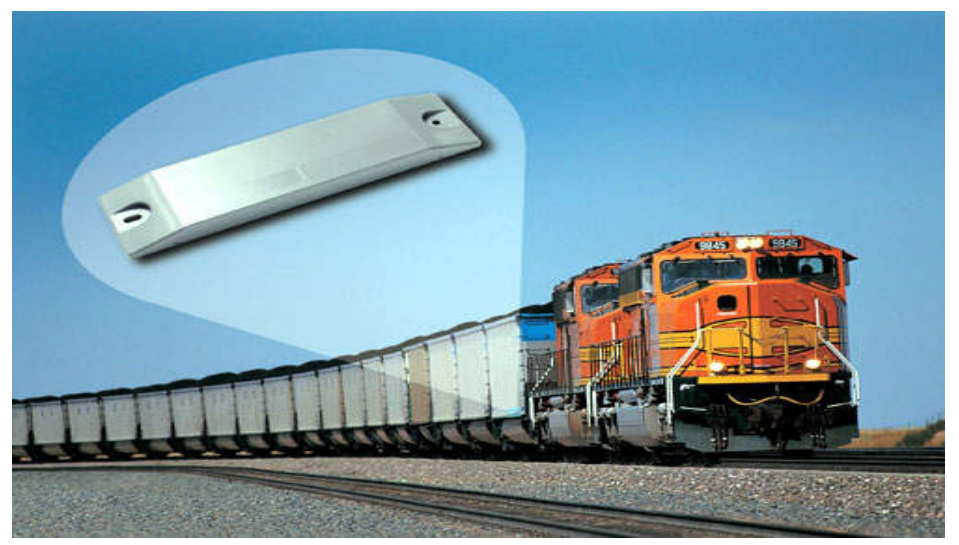

[Source: (French, 2008)]

Figure 4

The Indian railways too have started RFID tagging of goods wagons and the passenger coaches. Around 22,000 freight trains and 1,200 passenger coaches have already been equipped with RFID tags and it is expected that by the year 2021, all the coaches and engines (around 350,000) will be equipped with RFID tags. About 3,500 static RFID readers will read and send data to a central control centre, and the data can be read even if the train speed is 182 $\mathrm{km} /$ hour. RFID system will help the Indian railways to monitor the wagons and the passenger coaches. The RFID tag will provide not only the coach number but also all the information including its construction history. This will reduce network problems, eliminate connectivity problems, expedite maintenance and the railways will be able to exploit the resources with more efficiency. (Bakshi, 2020)

\section{SHOPPING/ RETAIL}

The traditional way of billing in a supermarket store is by scanning the barcode on the items. A typical procedure is given as below.

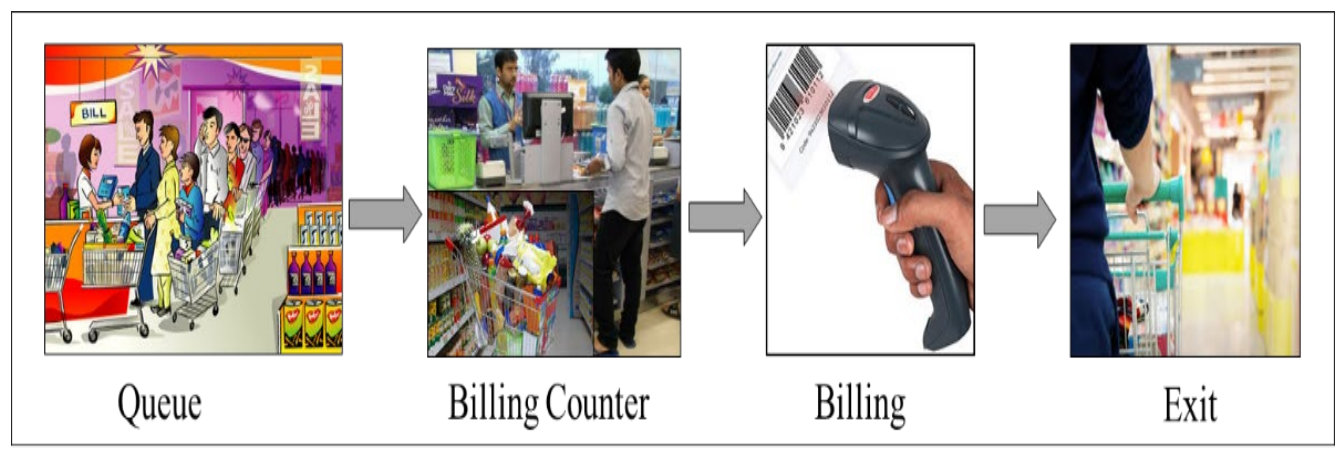

Figure 5

Source of images: (CloudMe Software Solutions - Supermarket POS software Dubai UAE, n.d.), (Instor Bill Counter, n.d.), (7 Best Barcode Scanners in India: Reviews \& Buying Guide 2020, 2020), (Empresa catarinense desenvolve automatização para higienizar carrinhos e cestas de mercados, 2020)

1) Selecting buy items in the supermarket and putting them in a cart.

2) Bringing cart to the billing counter, picking items from cart and placing them on the counter.

3) Itemized billing being done at the counter by using barcode reader.

4) Placing all the billed items back in cart or carry bags. 
The billing procedure and the time can be reduced by using a RFID system. As RFID doesn't need a 'line of sight' for functioning, there is no need to remove the RFID tagged items from the cart to place over the counter and to again put them back into the cart/ carry bags after the billing is over. Instead, when the cart is brought near the billing counter RFID sensing area, the billing system automatically reads all the items in the cart and generates the bill. The people pay the bill and exit the supermarket with ease, saving their valuable time.

(Jituri, 2020)

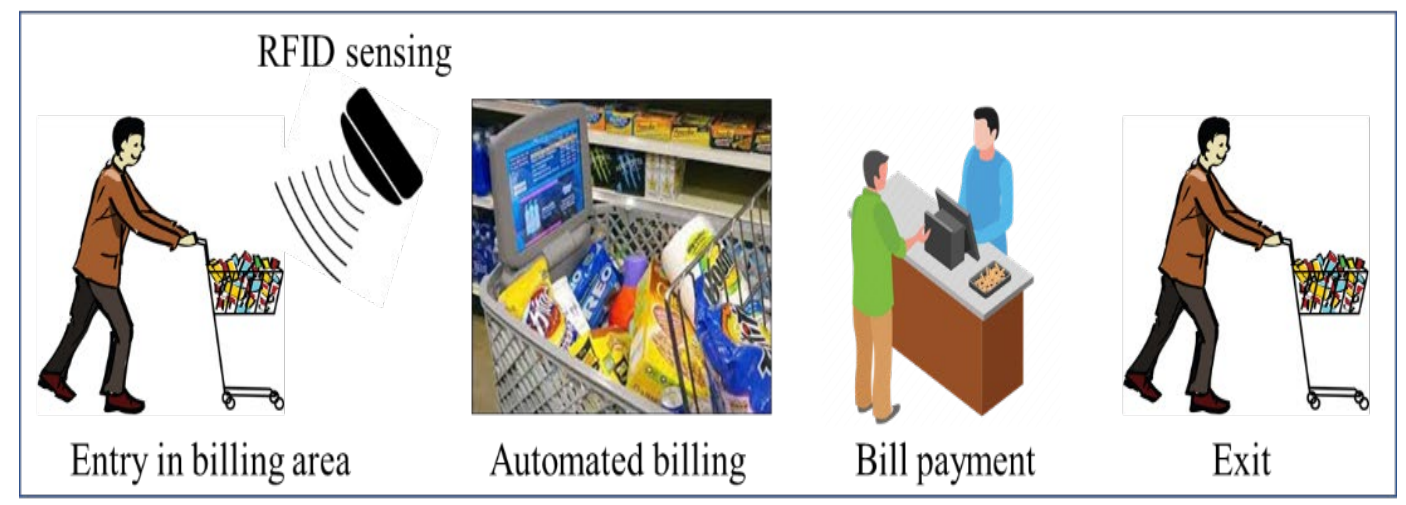

Figure 6

Source of images: (Free Clipart Of A Man Pushing A Grocery Shopping Cart - Pushing Force, n.d.), (Miller, 2008), (Billing counter, food court, food point, food street, food yard icon, n.d.)

\section{AGRICULTURE}

RFID technology is being successfully tested in agriculture in the areas of environmental monitoring, irrigation, specialty crops and farm machinery, fruit harvesting and packaging. This technology also plays an important role in cattle and poultry farming; for example, tagging of animals like cows, sheep, pigs, hen etc. allows the farmer to have superior traceability, better breeding control and data collection about every animal of the herd. With specialized RFID tags and readers designed for warm and humid conditions, it is possible to collect data in the greenhouses. The growth time, moisture content, equipment management and even personnel management, their access control and their working time can also be managed with the help of RFID technology. RFID can help in storage, distribution and sales of the agricultural products. (Kumar \& Srivastava, 2018)

\section{LIBRARY}

The library management using RFID tags is easy and convenient. The books are attached with a RFID tag, which are then interconnected through RFID reader, computer network and application software. The library staff can handle lending, returning, sorting, tagging, location tracking, shelf management, anti-theft detection of the books, using the RFID tags. The book is issued using the information on the RFID tag; however, the tracking/ surveillance of the RFID tag is deactivated for the issued book, to protect privacy of the person. Or the range of the RFID antenna can be kept limited, say within the premises of the library. (Pandey \& Mahajan)

There are some possible limitations of the RFID technology like standardization requirement (communication, protocol), cost, collision of data, optimal choice of frequency, faulty manufacturing of tags, deficient detection of tags, technology obsolescence/ change, privacy and security issues and vulnerability to virus attacks etc. (Kaur, Sandhu, Mohan, \& Sandhu, 2011)

Like the other technologies, there are potential risks to RFID technology too in the dimensions of security in terms of availability, integrity and confidentiality. The examples include denial of service, jamming, cloning, eavesdropping, malware, authentication and skimming. The tags and readers are not the only components of RFID systems that require security protection; the application software, network and database components are also subject to information security risks. To ensure RFID security, a mix of technical and non-technical controls are required to prevent and mitigate the risk. However, with various types of controls, the degree of sophistication, 
robustness, complexity and the cost differ. As a result, there is no one-size-fits-all RFID security measure that would efficiently address a given class of risks in all the possible situations and at low cost. Like any other technology, the appropriate level of RFID security requires striking the right balance between the value of the assets to protect, the possible damages an attack could generate, potential impact on privacy when information related to individuals is used and the risks. (OECD, 2008)

Besides the data leakage/ hacking, the potential risks to privacy are also important concerns for individuals and the organizations; namely real time tracking, invisibility of data collection, profiling, interoperability of technology, transparency and consent etc. (OECD, 2008)

\section{CONCLUSION}

With so many prospective uses of RFID technology in various fields and areas, it is expected that the limitations and risks connected with the RFID system will be adequately addressed. By choosing right RFID system and technology (active/passive tag, chip/chip-less tag, near-field/ far-field sensing), the security and the privacy issues can be dealt with, which is a very important aspect of consideration. With growing utilization of RFID, the cost will be reduced, and customized solutions will be available. The emerging areas for RFID applications are in healthcare, aviation, supply chain management, smart university, travel, and many more. The new technology RFID products will further result in ease of life in the future.

\section{SOURCES OF FUNDING}

This research received no specific grant from any funding agency in the public, commercial, or not-for-profit sectors.

\section{CONFLICT OF INTEREST}

The author have declared that no competing interests exist.

\section{ACKNOWLEDGMENT}

None.

\section{REFERENCES}

[1] 7 Best Barcode Scanners in India: Reviews \& Buying Guide 2020. (2020, January 6). Retrieved July 27, 2020, from https://homezene.com/: https://homezene.com/best-barcode-scanners/

[2] Bakshi, G. (2020, January 31). What is RFID Tag? Over 3.5 lakh coaches to be equipped with smart tags. Retrieved July 27, 2020, from www.jagranjosh.com/: https://www.jagranjosh.com/current-affairs/what-isrfid-tag-over-35-lakh-coaches-to-be-equipped-with-smart-tags-1580453778-1

[3] Billing counter, food court, food point, food street, food yard icon. (n.d.). Retrieved July 27, 2020, from www.iconfinder.com/:

https://www.iconfinder.com/icons/3972108/billing_counter_food_court_food_point_food_street_food_yard _icon

[4] Biometric Rf - Rfid Software. (n.d.). Retrieved July 28, 2020, from www.clipartkey.com/: https://www.clipartkey.com/view/TiJRhJ_biometric-rf-rfid-software/

[5] CloudMe Software Solutions - Supermarket POS software Dubai UAE. (n.d.). Retrieved July 27, 2020, from www.clipartkey.com/: https://www.clipartkey.com/view/bRbJbJ_free-clipart-of-a-man-pushing-a-grocery/

[6] Cui, L., Zhang, Z., Gao, N., Meng, Z., \& Li, Z. (2019, September 17). Radio Frequency Identification and Sensing Techniques and Their Applications-A Review of the State-of-the-Art. MDPI Journal, 19(18). doi:10.3390/s19184012 
[7] Empresa catarinense desenvolve automatização para higienizar carrinhos e cestas de mercados. (2020, May 13). Retrieved July 27, 2020, from www.nsctotal.com.br/: https://www.nsctotal.com.br/noticias/empresacatarinense-desenvolve-automatizacao-para-higienizar-carrinhos-e-cestas-de

[8] Free Clipart Of A Man Pushing A Grocery Shopping Cart - Pushing Force. (n.d.). Retrieved July 28, 2020, from www.clipartkey.com/: https://www.clipartkey.com/view/bRbJbJ_free-clipart-of-a-man-pushing-a-grocery/

[9] French, P. (2008, March 16). RFID and Rail: Advanced Tracking Technology. Retrieved July 27, 2020, from www.railway-technology.com/: https://www.railway-technology.com/features/feature1684/

[10] Instor Bill Counter. (n.d.). Retrieved July 27, 2020, from www.indiamart.com/: https://www.indiamart.com/proddetail/bill-counter-20320531997.html

[11] Jituri, V. V. (2020, February 11). How RFID is going to reduce billing time at Supermarket. Retrieved July 27, 2020, from https://eitfaridabad.com/: https://eitfaridabad.com/how-rfid-is-going-to-reduce-billing-timeat-supermarket/

[12] Kaur, M., Sandhu, M., Mohan, N., \& Sandhu, P. S. (2011, February). RFID Technology Principles, Advantages, Limitations \& Its Applications. International Journal of Computer and Electrical Engineering, 3, 151-157. $\begin{array}{llll}\text { Retrieved July } & 25, & \text { from }\end{array}$ https://pdfs.semanticscholar.org/5571/64fee5bd2d0a7add956de25d2ab2124fece7.pdf

[13] Kumar, V., \& Srivastava, A. (2018, March 12). The Role of RFID in Agro-Food Sector. Agricultural Research \& Technology Open Access Journal, 14(4), 121-125. doi:10.19080/ARTOAJ.2018.14.555924

[14] Miller, P. (2008, January 14). Microsoft and MediaCart prepping self-checkout carts, with RFID, video and grocery lists for good measure. Retrieved July 27, 2020, from www.engadget.com/: https://www.engadget.com/2008-01-14-microsoft-and-mediacart-prepping-self-checkout-carts-withrfid.html

[15] Mitsubishi Heavy Industries Machinery Systems. (2018). Toll Collection System with RFID Technology. Retrieved July 26, 2020, from www.mhi-ms.com/: https://www.mhims.com/jp/products/its/download/pdf/toll.pdf

[16] Nair, H. (2011, June 12). Electronic toll collection: Smooth ride on highways. Retrieved July 26, 2020, from www.thehindubusinessline.com/: https://www.thehindubusinessline.com/economy/logistics/Electronictoll-collection-Smooth-ride-on-highways/article20254387.ece

[17] NFC Reader Writer UID uitlezen. (n.d.). Retrieved July 28, 2020, from www.nfcsupport.nl/: https://www.nfcsupport.nl/product/nfc-reader-writer-uid-uitlezen/

[18] OECD. (2008). RFID Radio Frequency Identification. OECD Ministerial Meeting, Seol. Retrieved July 25, 2020, from https://www.oecd.org/sti/ieconomy/40892347.pdf

[19] Pandey, P., \& Mahajan, K. D. (n.d.). Application of RFID Technology in Libraries and Role of Librarian. Retrieved July 25, 2020, from http://eprints.rclis.org/: http://eprints.rclis.org/15253/3/RFID.pdf

[20] Parkash, D., Kundu, T., \& Kaur, P. (2012, September). THE RFID TECHNOLOGY AND ITS APPLICATIONS: A REVIEW. International Journal of Electronics, Communication \& Instrumentation Engineering Research and Development (IJECIERD), 2(3), 109-120. Retrieved July 25, 2020, from https://www.researchgate.net/publication/232575248_THE_RFID_TECHNOLOGY_AND_ITS_APPLICATIONS _A_REVIEW

[21] RFID reader clip art. (n.d.). Retrieved July 28, 2020, from www.clker.com/: http://www.clker.com/clipartrfid-reader.html

[22] Singh, K., Saha, P., Karmakar, C., \& Dutta, S. K. (2018). Automated Toll Collection System using RFID. Project report, RCC Institute of Information Technology, Electronics \& Communication Engineering, Kolkata. Retrieved July 26, 2020, from https://rcciit.org/students_projects/projects/ece/2018/GR4.pdf

[23] The different uses of RFID readers in India. (n.d.). Retrieved July 28, 2020, from http://daphnesystems.blogspot.com/: http://daphne-systems.blogspot.com/2019/01/the-different-uses-of-rfid-readersin.html 